\title{
SHEEP FARMING ON THE PUMICE LANDS OF THE CENTRAL PLATEAU
}

\author{
G. A. BROWN \\ Farmer, Tihoi, Taupo
}

Abstract

An outline is given of the development and problems of a Crownballoted farm since settlement 12 years ago. Its physical characteristics and limitations are indicated, Stocking policy and performance to date are outlined. Supplementary feeding systems for summer and winter requirements of stock are examined as a process to development of new pastures and lucerne.

Problems with the persistence of perennial ryegrass pastures are also discussed. A large plot trial comparison of some major perennial ryegrass cultivars has been established in a new grass paddock under grazing, and some measurements and observations recorded. Performance of the standard Ruanui ryegrass was notably inferior to other strains of ryegrass.

The importance of adequate subdivision is recognized and an outline is given of the various types of fencing systems, including electric.

Advantages and problems of sheep farming in the pumice country are documented, as well as the management methods evolved to minimize the disadvantages to allow continued good stock and farm production.

IN 1967 my wife and I took over a sheep and cattle, Lands and Survey ballot farm at Whakamaru, north-west of Taupo. The farm consists of 266 ha with an easy rolling contour and a yellowbrown pumice loam of Taupo origin. Forty hectares of the farm along streams has been permanently retired from grazing by the Waikato Valley Authority for erosion control purposes. The altitude ranges from 450 to $550 \mathrm{~m}$, and the average rainfall is $1480 \mathrm{~mm}$. Water is supplied by a deep well pump and permanent streams.

At settlement, my stock was 1150 Romney ewes, 350 hoggets, 70 Angus cows, and 26 rising 2-year Angus heifers. This was 11.3 s.u./ha. This winter (1979) the farm is carrying a total of 2790 stock units, or 12.3 per hectare, consisting of 1950 Coopworth ewes, 450 ewe hoggets, and 95 Friesian X Angus cows.

The stocking rate was decreased this year from the previous 2 years of 3250 stock units, or 14.3 per hectare, for two reasons the 1978 drought (which appeared likely to continue into 1979), and to maintain stock performance in the face of a growing grass 
grub problem. This reduction was achieved by selling all replacement cattle and culling the ewe hoggets fairly severely.

My sheep policy has been to fatten all wether lambs and cull ewe lambs, keeping the better ones for replacements. Ewes are culled on constitution and are sold to the works. Over the past 3 years, lambing percentage have been 108, 117 and 108\%, respectively, with prime lamb weights ranging between 13.5 and 15 $\mathrm{kg}$, and wool production averaging $10250 \mathrm{~kg}$, or $45.5 \mathrm{~kg} / \mathrm{ha}$. Hoggets are shorn in September, ewes in December, and lambs in January.

From the herd of run cows all weaner steers are sold. The heifers are retained to calve as 2-year-olds. Those not calving within two breeding cycles are fattened and sold on the spring butchers' market.

For the past 15 years Murray Grey bulls have been used. The cows are all recorded in Beef Plan, and about $20 \%$ are culled per year using these records. A disappointing point is that the Murray Grey-cross heifers have not performed very well and quite a high proportion have been culled. With selling the yearling heifers in spring 1978 and weaner heifers in 1979 because of the drought and grass grub, there are now very few Murray Grey-cross cows in the herd. If I continue to carry breeding cows, I will either buy Angus or Hereford $\times$ Friesian weaners or rear suitable bobby calves. Murray Grey-cross weaners sell very well and thrive from a fattening point of view. Calving has averaged about $95 \%$.

\section{FERTILIZER}

The annual maintenance dressing on pasture is $300 \mathrm{~kg} / \mathrm{ha}$ of $30 \%$ potassic serpentine superphosphate with cobalt. Lucerne which is grazed receives the same, and lucerne harvested for silage or hay receives two dressings of $300 \mathrm{~kg} / \mathrm{ha}$ of $30 \%$ potassic superphosphate. Swede crops receive $600 \mathrm{~kg} / \mathrm{ha}$ of an N, P, K mix with borax, with new grass sowings receiving 800 to $1000 \mathrm{~kg} / \mathrm{ha}$ of $15 \%$ potassic superphosphate.

\section{WINTER SUPPLEMENTARY FEED}

Ever since I took over the farm swedes have been grown, usually between 16 and 28 ha. Inclusion of approximately $100 \mathrm{~g}$ turnip seed/ha with the swede seed produces a more reliable crop on dry and less fertile areas.

Originally I used to make about 6000 bales of luceme hay. My neighbour and I did all our own harvesting, but the workload 
became too great, so we changed to the Heston 1.25 tonne stacks, which require much less labour and can be stored in the open. We used this system for 3 years and it seemed quite satisfactory, although I think there may have been more wastage than was at first apparent. These stacks are difficult to feed out to sheep, although quite satisfactory for cattle.

This year I have changed to precision-chopped wilted lucerne silage (harvesting 20 ha) to achieve a fully mechanized system of feeding a high quality supplement to all classes of stock.

The cows this year were wintered on swedes, then block-grazed on saved pasture leading up to calving and post-calving.

Ewes and hoggets were run together on swedes with breaks of 1 to 2 ha, which usually lasted. 5 or 6 days. They were given a grass paddock between breaks.

\section{SUMMER FEEDING}

Because of the need to renew pasture severely damaged by grass grub and to provide fattening and flushing feed, last year I grew 6 ha of Wairoa brassica, which yielded quite well.

Lucerne is used to feed all classes of stock, although I try to keep the ewes. off it when approaching tupping. Both the lucerne and stock appear to do better if a quick grazing is carried out.

The usual sequence after weaning is lambs first grazed for. 2 or 3 days, followed by ewes, and then perhaps cows, to clean up. Salt is available to all stock on lucerne.

\section{DISTRICT ADVANTAGES AND PROBLEMS}

The advantages and problems of this district as I see them, and have influenced my management decisions, are as follows:

\section{AdVAntage $S$}

(a) Dry conditions underfoot, There is very little mud even under wet winter conditions. Good drying for shearing and haymaking.

(b) Good roading to shopping and sale centres.

(c) A choice of stock markets with the Waikato, Bay of Plenty and Hawke's Bay areas being reasonably handy.

(d) Good general stock health. 
Problems

(a) Long winter with slow and unreliable spring growth.

(b) Dry summers are normally experienced.

(c) Exposure to cold winter winds and drying summer wind.

(d) Grass grub infestation is quite severe in localized areas, and general throughout the district.

(e) Poor persistence of new sown pasture.

The long winter makes it necessary to have ample stocks of supplementary feed, which is one reason for the comparatively large area of winter crop, and also for the large area of lucerne to enstire good supplies of hay or silage.

When the property was first settled, lambing occurred at the end of August. The lambs grew well until docking; then their growth slowed down and the ewes lost condition. I noticed that the later lambs were just as good as the early ones by weaning, so I have now adopted a policy of later lambing.

I now put the rams out on 28 April for 5 weeks. Lambing commences on 20 September and by the middle of October the first of the lucerne paddocks are ready to graze. The ewes and' lambs are mobbed up and the rotation is started. Approximately 90\% of the ewes lamb in the first cycle. This later lambing gives time to sow young grass or luceine into the swede paddock before lambing, reduces sleepy sickness, milk fever and wool break as a result of better grass growth, and allows more time in the autumn to improve the ewes' condition after a dry spell.

\section{REDEVELOPMENT INTO LUCERNE AND NEW PASTURES}

To a certain extent the grass grub problem has been overcome by sowing about a quarter of the farm into lucerne. Apart from following the guidelines for fertilizer requirements, I feel the most important aspect of lucerne establishment is thorough ground preparation. All the lucerne has been sown following a swede crop, and cultivation with a spring tyne cultivator, tyne harrows, and frequent rolling. Seed was sown through the smsll seeds box at $8 \mathrm{~kg} / \mathrm{ha}$ on a deep vee roller, with lime and serpentine superphosphate sown through the fertilizer box. In the past Wairau was used, but last year Pioneer 521 was sown. This established strongly and could possibly be sown at a lighter rate. This year a cover crop of rape was also sown. All the luceme is grazed at some stage during the year, while hay' or silage is taken from the better-contoured paddocks. 
For some years I have been concerned at the rapid deterioration of newly sown pastures. Originally I sowed a traditional mix of Ruanui and Manawa ryegrasses, cocksfoot, crested dogstail, and white and red clovers (30 kg/ha), but since only initially ryegrass and white clover survived I changed to a Ruanui/ white clover mixture sown at $20 \mathrm{~kg} / \mathrm{ha}$. Still not satisfied, with these Ruanui-based pastures failing dismally and most plants dying out within 2 years, I tried a paddock of Ellett ryegrass (then called Mangere ryegrass) which appeared to be successful.

Because of the apparent benefits from sowing Ellett rather than Ruanui ryegrass; a grass species trial was sown on the farm in September 1977. With the co-operation and assistance of Robin Gordon (MAF, Taupo), additional grass mixtures were included. The following mixtures were sown in $650 \mathrm{~m}^{2}$ replicated plots:

Ellett ryegrass — produced by A. Yates \& Co Ltd

$\begin{array}{ll}\text { Nui ryegrass } & \text { ) Sown at } \\ \text { Ruanui ryegrass ) Produced by Grasslands } & \text { f } \\ & 25 \mathrm{~kg} / \mathrm{ha}\end{array}$

Ellett ryegrass $(8 \mathrm{~kg} / \mathrm{ha})$ and $\mathrm{G} 4710$ tall fescue $(9 \mathrm{~kg} / \mathrm{ha}$; from Grasslands Division, DSJR).

Ellett ryegrass (8 kg/ha) and G14 Phalaris aquatica $(6 \mathrm{~kg} / \mathrm{ha}$; from Grasslands Division, DSIR).

All were sown with white and red clovers $(2$ and $1 \mathrm{~kg} / \mathrm{ha}$. respectively). The tall f\&cue and phalaris were included as part of a district evaluation to see if they would establish, to determine their seasonal production, and also to assess their ability to produce in the presence of high grass grub populations. Grass growth on the trial is regularly monitored jointly by staff of A. Yates \& Co. Ltd and Ministry of Agriculture and Fisheries. The rest of the trial paddock was sown with Ellett ryegrass $(11 \mathrm{~kg} / \mathrm{ha})$ and white and red clovers ( 3 and $1 \mathrm{~kg} / \mathrm{ha}$, respectively). The paddock was topdressed with $15 \%$ potassic serpentine superphosphate $(1000 \mathrm{~kg} / \mathrm{ha})$ and lindane $(11 \mathrm{~kg} / \mathrm{ha})$ before sowing.

The most important trend from the trial so far is the greater production and persistence of Ellett and Nui ryegrasses relative to Ruanui. This parallels the improved pastures that have resulted from my sowing Ellett rather than Ruanui ryegrass. In autumn and winter of 1979 , Ellett ryegrass has also shown out over Nui. The relative production figures are: 


$\begin{array}{lr}\text { Nui } & 100 \\ \text { Ellett } & 129 \\ \text { Ruanui } & 50 \\ \text { Ellett and fescue } & 130 \\ \text { Ellett and phalaris } & 123\end{array}$

While both fescue and phalaris can be readily identified on the trial, neither has been able to compete against the more vigorous Ellett ryegrass. I think Ellett ryegrass should be sown at a low seeding rate to reduce its suppression of white clover. It appears to thrive under rotational grazing that is hard and quick.

\section{SUBDIVISION AND SHELTER}

Originally the farm consisted of only 9 paddocks which averaged 20 ha each. The aim has been to divide the farm into 6- to B-ha paddocks, all, to be served from an access lane. At present there are 30 paddocks, with one large paddock still to be subdivided. Various fencing systems have been tried, such as netting, standard B-wire post and batten, 9- or lo-wire soil conservation, grass fence, and a type of flexifence. This latter type has proved to be a good compromise between economy, speed of erection, and stock-holding ability. It consists of eight $2.5 \mathrm{~mm}$ wires (top wire electrified), $1.07 \mathrm{~m}$ high, supported by posts up to $10 \mathrm{~m}$ apart depending on contour, with $820 \mathrm{~mm}$ long battens at 3 or 4 per panel. This fence costs $\$ 1150 / \mathrm{km}$ in our area, or $\$ 11 / 20 \mathrm{~m}$ for material and $\$ 12 / 20 \mathrm{~m}$ for labour.

The grass fence is quite successful, but more suited to subdividing existing big paddocks rather than subdividing a complete farm. The drain on the energizer is quite severe in good growing conditions. The effect of wind can be eased by shelterbelt planting. Plantings in Waikato Valley Authority conservation areas prove to be valuable as they encourage stock into the valleys to seek shelter and shade. This helps to stop the transfer of fertility from the low parts of the paddock to the ridge tops.

\section{CURRENT MANAGEMENT AND THE FUTURE}

The result of these various improvements has made farming here more satisfying. In particular, the establishment of Ellettbased new pastures and a sufficient area in lucerne both help to reduce the climatic factor inhibiting production.

Changing from Romney to Coopworth sheep has also allowed some degree of easy care, plus scope in fertility selection. Al- 
though I have not done anything about selecting the more fertile replacement ewes, I have been buying single entry rams with a high fertility background as well as high wool weights. In the future I intend to concentrate more on this aspect and use hogget fleece weighing as a selection tool. The lucerne has enabled me to carry lambs to higher weights. In earlier years I was happy to finish lambs at 12.5 to $13 \mathrm{~kg}$; now I aim for 14 to $15 \mathrm{~kg}$.

Rotational grazing has made stock movements more orderly and purposeful, aided by the central lane which has made.access to all parts of the farm quicker and easier. Farm bikes provide fast and economical transport. They also make it possible for young members of the family to do useful jobs around the farm.

I now do all cultivation work and 'most of the harvesting -work myself. I find this more satisfying than depending on contractors, who are usually overworked at the times I want them. Levelling the rough patches of paddocks has made a big difference to cultivation times and subsequent haymaking, etc. For this purpose I was able to buy an old model D7 bulldozer which has proved to be an asset.

When cultivating I have found erosion to be a problem. Making a 'series of small dams down gullies has stopped the flow of heavy rainstorms and eliminated the scouring that used to occur.

I have a reasonably well-equipped workshop with electric and gas welding equipment, a large capacity drill and grinding equipment. This has enabled me to build or modify farm equipment such as a quick-coupling transport tray, an automatic pickup hitch for farm trailers and feed wagon, and a front-end loader to handle fine-chop silage. These modifications have made operations on a one-man farm safer and easier.

All in all, I am happy to be farming here and look forward to the challenges of the future. The areas I would like to concentrate on are higher stock carrying and higher stock performance. Good pastures, efficient feed conservation, good subdivision and more attention to stock selection should ensure this. 